Volume 3 Issue 1, March 2019: pp. 37-49. Copyright (c) 2019 HOLREV. Faculty of Law, Halu Oleo University, Kendari, Southeast Sulawesi, Indonesia. ISSN: 2548-1762 | e-ISSN: 2548-1754. Open Access at: http://ojs.uho.ac.id/index.php/holrev/

\title{
The Licensors' Economic Right for Creative Commons Licensed Works Used for Commercial Purposes in Indonesia
}

\author{
Dewi Sulistianingsih \\ Lecturer in Faculty of Law, Universitas Negeri Semarang \\ Gedung K Kampus Sekaran Gunungpati Semarang \\ E-mail: dewisulistianingsih21@mail.unnes.ac.id \\ Gianefi Safitri \\ Staffon Ministry of Law and Human Rights of Republic of Indonesia, \\ Directorate General of Immigration, \\ Teluk Tering, Batam Center, Kota Batam, Kepulauan Riau \\ E-mail: gianefi22@gmail.com
}

\begin{abstract}
A Creative Commons License is a public license which can be used by a creator or an inventor regarding a royalty-free license both for commercial and noncommercial uses. The commercial use of a creation financially inflicts the licensor since there is no economic right from the royalty from the user of the creation. This paper is a result of a study which applied a normative juridical approach. The study aims to find out the protection of economic right of the licensor for his or her creation, which is under creative commons license, which is used for commercial purposes. The economic right protection of the licensor whose work is under common creative license which is used commercially is the same as that of other licenses because a creative commons license is basically the same as other license agreements which bind parties involved in an agreement. The protection is given through the Act of the Republic of Indonesia Number 28 Year 2003 Concerning Copyright.
\end{abstract}

Keyword: License; Economic Right; Creation; Creative Commons

\section{INTRODUCTION}

A creation which is protected by a copyright still faces similar problems as other creations. The problems are due to plagiarism and "copy paste" 1 activities which certainly

1 "Copy paste" is a phrase used to describe someone's activity who takes without the owner's permissions or claims someone else's paper to his or hers or in other words plagiarism. 
economically inflict the creator or the inventor. This problem is because it easy to access or download those creations. The download is usually carried out illegally and without any consent from the creator(s) and it inflicts the creator both morally or economically. The protection for a creation, which is extremely needed by a creator, has already been realized in the latest Copyright Act which is Act of the Republic of Indonesia Number 28 Year 2003 Concerning Copyright. The protection prevents from plagiarism and copy-paste cultures which are getting more alarming and they can trigger the cases of copyright violations. One of the causes of the violations of the copyrights is the economic value resulted from the creation.

The technological development also becomes one of the factors that promote the development of copyright provisions. The regulations in the copyrights are generally conditioned for manual applications regarding physical creations which generally, in their applications, do not involve copying and multiplying activities. Books, especially physical ones, are supposed to be read because a reading activity is a natural activity for those books and reading physical books does not require someone to copy and multiply the books. Digital or electronic books, however, may involve copying and multiplying or pasting the books. Therefore, nearly all activities related with digital media may trigger the implementation of copyright provisions regarding the violations, unless the activities are stated as reasonable activities. Such condition as stated by Lawrence Lessig as legal insanity which is created by the regulations. ${ }^{2}$

The easiness for an acknowledgement of a creation to become an inventor/creator's copyright is possible by the emergence of Creative Commons ${ }^{3}$. Creative Commons is a nonprofit organization which is founded by Lawrence Lessig. The organization is situated in Massachusetts, United States of America. It provides copyright licenses which have been standardized with a copyright to distribute his or her creations. The objectives of Creative Commons are to support and enable creators to permit general applications for their work

2 Lawrence Lessig, "CC Review: Lawrence Lessig on How It All Began”, Creative Commons, https://creativecommons.org/2005/10/12/ccinreviewlawrencelessigonhowitallbegan/, accessed on October 1, 2017.

3 Creative Commons is a non-profit organization which is founded by Lawrence Lessig, Han Abelson, and Eric Eldred focusing on expanding the coverage of creative work. 
without depending on costly and lengthy legal consultations or to detach their rights to put their work in the public domain. ${ }^{4}$

The protection offered by Creative Commons are that for work which is distributed via social media contents. Creative Commons offers protections for those works by licensing them as what we know as creative commons license which were established on December 16, 2002. The applications of this license differ from the registration of a copyright in the Directorate General of Intellectual Property since the latter requires registration fee. To get a creative commons license, a creator only needs to visit creative commons' website, i.e. www.creativecommons.org. He only needs to follow given instructions or guidelines. The application of a creative commons' license allows the inventor or creator to maintain his or her ownership of his or her creations or works, although he or she has given freedom for the public to download, distribute, or even alter or adapt the work for commercial purposes without having to obtain permission before as long as they give the creator(s) credits.

The process of licensing certainly involves rights and obligations for both the licensor or the licensee. The rights and obligations they have to perform will result in mutual benefits for both parties when using the creation or work. The licensor will earn an attribution right and he will get a royalty for his work while his obligation is to grant the licensee to use his work. The licensee's right and obligation are among others to make use of the licensor's work and pay royalty for the work.

The usage of creative commons' license consists of six (6) types of license which three of them can be used for commercial purposes. The licenses are creative commons by attribution $^{5}$, creative commons by attribution share alike ${ }^{6}$, and creative commons by attribution non-derivative ${ }^{7}$. While the other three licenses are for non-commercial

4 Till Kreutzer, Open Content: Practical Guidelines to Use Creative Commons Licenses, UNESCO, 2015, https://www.unesco.de/fileadmin/medien/Dokumente/Kommunikation/Open_Content_Leitfaden_in_i ndonesischer_Sprache.pdf, accessed on November 7, 2016 at 17:00 Western Indonesia Time page 14

5 Creative commons by attribution license is one of the creative commons' licenses which allows the creator to grant the licensee permissions to copy, distribute, and display the work and its derivatives by displaying the creator's name(s).

6 Creative commons by attribution-share alike is one of the creative commons' licenses which allows the creator to grant the licensee permissions to distribute the work's derivatives under the condition that the derivative is licensed using an identical license with that of the original and displaying the creator's name(s).

7 Creative commons by attribution non-derivative is one of the creative commons' licenses which allows the licensor to grant the licensee permission to copy, distribute, display, and present only the original work but not its derivative while still displaying the creator's name(s). 
purposes. The licenses are creative commons by attribution-non-commercial ${ }^{8}$, creative $^{-1}$ commons by attribution-non-commercial share alike ${ }^{9}$, and creative commons by attribution-non-commercial non-derivative licenses ${ }^{10}$.

Based on the paragraph 83 article 1 of Act of the Republic of Indonesia Number 28 Year 2003 Concerning Copyright, it is stated that a license agreement must be registered by a minister via a general registration. The license registration is carried out in order that the registration possesses a legal consequence to the third party. However, a license registration is a rare practice since there are not many people who carry it out. Moreover, a license registration has not been regulated in the government regulations.

According to the creative commons license agreement, a licensee can earn economic benefit from deriving a work which is licensed as creative commons for commercial purposes. However, the licensor does not earn any benefits from such usage because a creative commons license applied a royalty-free license. This situation is based on the Creative Commons Legal Code which states that "subject to the terms and conditions of this public license, the licensor hereby grants you a worldwide, royalty-free, nonsublicensable, non-exclusive, irrevocable license to exercise the licensed rights in the licensed material to ..."11 This legal code mentions that the creative commons license is royalty-free and non-exclusive.

Although a copyright is an exclusive right possessed by a creator or a licensor, he does not receive economic benefits from each use of his creation(s) since it is a moral and economic right. This is mentioned in the article 4 of Act of the Republic of Indonesia Number 28 Year 2003 Concerning Copyright which states that a copyright which was previously stated in the article 3a of Act of the Republic of Indonesia Number 28 Year 2003 Concerning Copyright is an exclusive right which comprises a moral and economic right. The implementation of the moral right is among others the inclusion of the creator's name

8 Creative commons by attribution-non-commercial is one of the creative commons' licenses which allows the licensor to grant the licensee permissions to copy, distribute, present, and display the work using noncommercial content.

9 Creative-commons by attribution-non-commercial-share alike license is one of the creative commons' licenses which allows the creator to grant the licensee permissions to adapt his work provided that it is not for commercial purposes both in the original form and in the derivative form.

10 Creative commons by attribution-non-commercial-non-derivative license is one of the creative commons' licenses which allows the creator to grant the licensee permissions to copy, distribute, present, and display the original work not its derivative for non-commercial purposes.

11 Creative Commons, Legal Code of Creative Commons License Attribution-Share Alike 4.0 Unposted, Creative Commons, http://creativecommons.org/by-sa/4.0/legalcode, article 2. Accessed on November 29, 2016 at 11.19 Western Indonesia Time. 
on the work, while the implementation of the economic right is when the creator receives royalty from his work because it is used by other people.

Creative commons licenses have accommodated the creator's moral right since it is stated in the license that the licensee has to mention the creator's name(s) for the work they derive. However, creative commons license does not adequately accommodate the creator's economic right or the licensor for his creation which is used for commercial purposes in order that the creator can gain economic profit since it is an exclusive right that the creator has to obtain.

\section{METHOD}

The research makes use of a qualitative approach, a research method which creates descriptive data. In accordance with the research problems, the study uses normative juridical research method. This method is conducted by analyzing and interpreting theoretical matters which involve principles, concepts, doctrines, and legal norms which are related with the justifying a legal case. The normative juridical approach is an approach which is based on primary legal materials which requires the researcher to analyze law theories, concepts, principles as well as the regulations which are related with this research. The approach is also known as literature study which means that the researcher studies books, regulations and other documents which are related with the research.

\section{ANALYSIS AND DISCUSSION}

The distribution of a work through social media helps encourage the establishment of creative economy which also helps the creator introduce his work. Creators opt prefer to use social media since they offer ease when they want to announce their works. However, the convenience offered by the social media leads to problems since the works shared in the media can be easily plagiarized by irresponsible individuals. These actions surely prevent the creators from obtaining their moral and economic rights.

In regards with plagiarism activities, Lawrence Lessig, a professor of Harvard University, created a system through which internet users who copy or multiply a work does not infringe any copyrights. The system is now known as creative commons licenses. The creative commons licenses are public licenses which can be obtained by anyone and is non-exclusive. The license does not require a work user to obtain permissions directly from the creators or the licensors since they have previously licensed their works using 
creative commons licenses. There are three types of creative commons licenses which can be used for commercial purposes, they are creative commons by attribution, creative commons by attribution-share alike, creative commons by attribution-non-derivatives. In addition, there are three other licenses for non-commercial purposes, like creative commons by attribution, creative commons by attribution-share alike, creative commons by attribution-non-derivatives.

The development of creative commons licenses in Indonesia has increased rapidly. It can be seen since there are more works which are using creative commons licenses. The following diagram shows the percentage of creative commons licenses usage. The occurrence and invalidation of lawsuit regarding rights or prosecution.

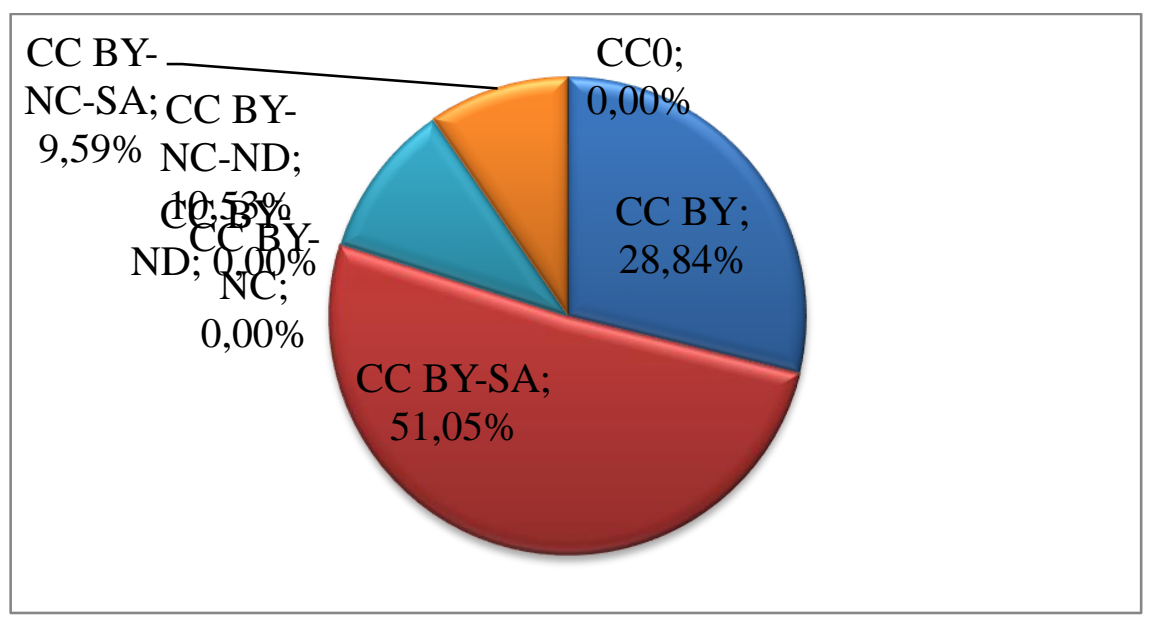

Diagram 1.1 The percentage of Creative Commons Licenses in 2016 Source: Creative Commons Indonesia 2016

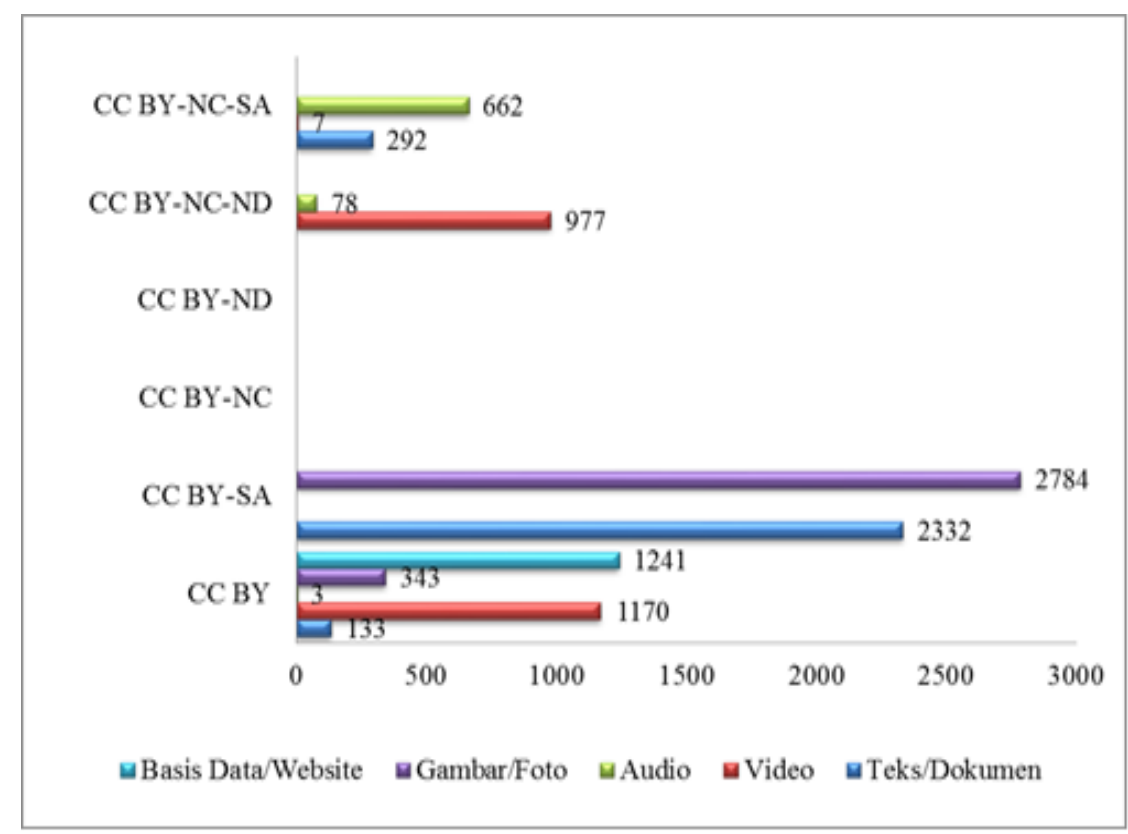

Diagram 1.2 A graph showing works which are using Creative Commons licenses in 2016 Source: Creative Commons Indonesia 2016 
According to the Article 83 paragraph 1 of Act of the Republic of Indonesia Number 28 Year 2003 Concerning Copyright, a license agreement must be registered in the general registration in Directorate General of Intellectual Property. Later, the registration of the license agreement will have a legal consequence to the third party. This has been constituted in the Article 83 paragraph 3 of Act of the Republic of Indonesia Number 28 Year 2003 Concerning Copyright.

The license agreement registration still faces obstacles since the regulations regarding the license agreement is still unavailable. Since the license agreement registration has not been regulated in the government regulation, the implementation of the agreement registration still faces several obstacles and is unable to be processed in the Directorate General of Intellectual Property.

The absence of the license agreement registration procedures results in a condition is which there are only few people who register their license agreements. Therefore, it is very rarely that we can find parties who carry out license agreement registrations. Beside a problem due to the absence of the regulations,

A Creative Commons license agreement is a general licensing agreement, and according to Article 83 paragraph (1) Law Number 28 of 2014 on Copyright, it is required to be registered. However, the Creative Commons license agreement is an exception. The exception is obtained after coordination between Creative Commons Indonesia and the Directorate General of Intellectual Property.

The Creative Commons license does not need to be registered because the license is not used to gain economic profits. The profits referred to are royalties, in the creative commons license agreement it does regulate the absence of royalties, because in each type of creative commons license explains that the creative commons licenses are those which are free of royalties and non-exclusive in any creative license legal code commons like: ${ }^{12}$

Subject to the terms and conditions of this public license, the licensor hereby grants you a worldwide, royalty-free, non-sublicensable, non-exclusive, irrevocable license to exercise the licensed rights in the licensed material to ...

The exception to the creative commons license agreement registration raises questions relating to Article 83 paragraph (3) of Law Number 28 of 2014 concerning

12 Legal Code of Creative Commons License Attribution-ShareAlike 4.0 Unported, http://creativecommons.org/license/by-sa/4.0/legalcode, Article 2, accessed on November 29, 2016 at 11:19 Western Indonesian Time. 
Copyright, which stipulates if the license agreement is not listed, the license will not have legal consequences for the third parties. The legal consequences caused by not doing the license agreement registration also do not apply to creative commons license agreements.

The protection given to a copyright along with the obligation to register licenses based on the economic growth stimulus theory is recognized that providing intellectual property protection is a tool of economic development. The protected intellectual property will have an influence on the country's economy because an intellectual property work such as a creation will have an influence on the economy of a country if it is used. Therefore, the country must provide protection for the works. The objects which need protection are not limited to the works only, but also to licensing agreements that hold a major influence on business development and indirectly will have an influence on the country's economic development. Such protection can be carried out with the existence of a license record so that it is clear who is entitled to use the work.

Even though the licenses do not regulate royalties, they give economic benefits to the users who use the works. The economic benefit can influence the economic development which is based on the economic growth stimulus theory, it is advisable that, whether the license regulates royalties or not, it still should get intellectual property protection. The protection which is now offered by a license agreement is through the registration of the license agareement. However, the registration exception regarding with a creative commons license which is based on the rationale that there is no royalty must still be carried out.

Based on the article 83 paragraph (1) of Act of the Republic of Indonesia Number 28 Year 2003 Concerning Copyright, it is explained that a license agreement must be registered in the general registration. The obligation of license registration applies to all license agreements, since there is no explanation which excludes a certain license including those of creative commons.

The obligation to register a license agreement according to article 83 paragraph (1) of Act of the Republic of Indonesia Number 28 Year 2003 Concerning Copyright gives an impact to the third party, since it explains that a license agreement will not have a legal implication to the third party if the license agreement is not registered. The exception for creative commons license registration will raise problems when such matters are ratified by the government, since based on the article 83 paragraph (1) of Act of the Republic of Indonesia Number 28 Year 2003 Concerning Copyright every license needs to be 
registered. This regulation also applies to creative commons licenses since the article 83 paragraph (1) of 2014 on Copyrights just mentions a license registration. Therefore, a creative commons license is no exception based on the article. However, when there is an exception for the creative commons license registration, there are two regulations which contradict, they are article 83 paragraph (1) of Act of the Republic of Indonesia Number 28 Year 2003 Concerning Copyright and the Government Regulation on the Procedures of License Registration. The implementation of license registration is because the creative commons licenses are license agreements which are subject to copyrights law even if the origin of the licenses are the United States where license registrations are not regulated. However, the creative commons licenses are applicable internationally and they are obviously subject to the copyright laws of the respective countries. Therefore, a creative commons license agreement is supposed to be registered in the general registration.

Apparently, there will complications that will happen when a creative commons license agreement is registered. The complications can be observed from the users of the license. Users who use works under creative commons licenses can be anybody and they can come from different countries which surely have different regulations from that applied in Indonesia. For example, the licensor is domiciled in Indonesia and the user is domiciled in the United States. The law in Indonesia requires that a license agreement be registered, while American law does not recognize license agreement registration. This condition leads to discrepancies between the licensor and the user regarding with the license agreement. Moreover, creative commons license agreement is non-exclusive which allows the licensor to grant permission to not only an individual but also to anyone who wishes to use the work. With the growing number of users who use works under creative commons licenses, there will be more licenses needed to be registered in regards with a particular work. It so happens because creative commons license work users do not only use one work only, but they possibly also use more than one work which is under the creative commons license. Since one user can use more than one work from different creators, there will be complications when the license agreement is required to be registered.

Interestingly, the exception of creative commons license registration allows the creator to distribute his works. In addition, there are more creators who allow his works to be distributed without considering their economic right by using the creative commons licenses. The initial objective of the creative commons license was to facilitate creators in 
distributing his works to be used by others. This condition implies that there is no necessity for the creator or the licensor to register their creative commons licenses in the Directorate General of Intellectual Property. Thus, the objective of the Creative Commons can be carried out properly and it will bring about positive impacts to the development of creativity in Indonesia to create more creative works.

The creative commons license is non-exclusive and royalty-free which means that there is no royalty given to the licensor for any use of his works whether it is for commercial or non-commercial purposes. The regulation regarding the royalty is also regulated in the creative commons license agreement. The regulation can be seen in the article 2 of creative commons license legal code.

According to the reward theory explained by Robert C. Sherwood, an acknowledgement of an intellectual work produced by an inventor/a creator/a designer is necessary, so the inventor/creator/designer needs to be awarded as a reward for his creative efforts in inventing/creating his intellectual piece. Based on the theory, a royalty is an appreciation rewarded to a creator for his work since his work entails an economic right which can result in rewards for the work.

However, the licensing process to the licensee which may include the licensee obligation to pay as the royalty to the licensor or the copyright holder can be excluded when both parties agree the otherwise. This is implied in the Article 80 paragraph (3) of Act of the Republic of Indonesia Number 28 Year 2003 Concerning Copyright which stipulates that in a license agreement, if agreed otherwise, the licensing process may include an obligation for the licensee to pay a certain amount of royalty to the licensor or the copyright holder during the license period. According to the above condition, the presence or the absence of a royalty in a license agreement depends on the parties involved in the agreement whether they are in favor of royalty or not. Royalties can also be included in the agreement and its amount is determined by the parties, and the parties can also opt out royalties and make it royalty-free.

Reward theory is not applicable to creative commons license since there is no royalty in the licenses. The royalty-free regulation makes a creator or licensor unable to obtain awards or rewards for his creations. In addition, the license does not agree with Recovery theory by Robert C. Sherwood which stated that a creator/an inventor/a designer has spent time, money, and energy to create an intellectual work and he deserves to get some in return for the time, money, and energy he has spent. When there is no 
royalty or reward for the work, the creator gets nothing for his time, money, energy he spent to create his work. Moreover, when the work is used for commercial purposes while the creative commons license does not regulate royalty, since the license allows the work to be used either commercially or non-commercially by a user when he chooses to use the work

The work usage using the creative commons license which does not regulate the royalty payment is against the law, since the license basically is made based on the agreement between both parties. The consensus principle in the Article 1320 paragraph (1) of Civil Codes states that the legal requirement of an agreement is when there is a mutual agreement between both parties. The consensus principle states that generally an agreement has formally been carried out when there is a mutual agreement between both parties. The agreement is an adjustment between the expectations and statements made by both parties. The decision to use the creative commons license itself in the creation is a mutual decision between the licensor and the user. Therefore, the parties involved in the agreement are bound with the agreement.

To that matter, the licenses that can be chosen by the licensor to allow users to use his work for commercial purposes are creative commons by attribution, creative commons by attribution-share alike, and creative commons by attribution-non-derivatives. The licenses above are royalty-free and commercial. If agreed by the licensor and the user, this regulation has bound both parties, Therefore, it is reasonable if the user uses the work for commercial purposes.

The impact of the licensor's willingness to allow his work to be used for commercial purposes without any royalty encourages more creative creations created by a creator using a license that does not require royalty. Besides, there will more users who will use the work that makes the work become more popular. However, we cannot deny that the permission to commercially use the work will cause many plagiarism practices towards the work which is certainly against the Copyright Acts.

The steps which can be carried out by the government regarding creative commons licenses problems as told by Andi Kurniawan who represents the Directorate General of Intellectual Property are that the protection for the Creative Commons licenses are similar to that given to other licenses, since creative commons licenses are regarded as intellectual property licenses. The protection refers to Intellectual Property Acts. Alifia Qonita Sudharto mentions a similar thing that the protection offered by the Copyrights Acts is 
already sufficient to give protection for both the licensor and the work users and when there is a legal problem emerging, it can be settled using the applicable Copyrights Acts. According to the article 95 paragraph (1) of Act of the Republic of Indonesia Number 28 Year 2003 Concerning Copyright, it is explained that a copyright dispute can be settled by an alternative dispute settlement, an arbitration, or a trial. A copyright dispute settlement needs to be intervened by the law enforcement when it has reached a trial level, and the authority which can settle the dispute is the Commercial Court.

\section{CONCLUTION}

The economic right of the licensor for his licensed work using the creative commons license for commercial purposes obtain similar protection for those licenses as stipulated in the Act of the Republic of Indonesia Number 28 Year 2003 Concerning Copyright. The economic right protection in this case is the royalty which the licensor will not obtain if he licenses his work under creative commons licenses even though his work is used for commercial purposes. This is because creative commons licenses are royalty-free. Based on the article 80 paragraph (3) of Act of the Republic of Indonesia Number 28 Year 2003 Concerning Copyright, the existence of a royalty depends on the parties involved in the agreement. Therefore, when the work is used for commercial purposes is not a law infringement, as long as the user obeys the content of the creative commons license agreement. This is not considered as a violation because the license is basically similar with other agreements which are created in accordance with the agreement and are supposed to be carried out by both parties since the agreement is binding. If it is regulated in the agreement that it is royalty-free, and it can be used for commercial purposes, it is because both parties have agreed to do so. However, we have to consider the concept of commercial use as a reasonable usage, so it will not be considered as a violation.

\section{BIBLIOGRAPHY}

Act of the Republic Of Indonesia Number 28 Year 2003 Concerning Copyright Creative Commons, Legal Code of Creative Commons License Attribution-Share Alike 4.0 Unposted, Creative Commons, http://creativecommons.org/by-sa/4.0/legal code, article 2. Accessed on November 29, 2016.

Kreutzer, Till, Open Content: Practical Guidelines to Use Creative Commons Licenses, Germany: UNESCO, 2015, https://www.unesco.de/fileadmin/medien/ 
Dokumente/Kommunikation/Open_Content_Leitfaden_in_indonesischer_Sprache. pdf, accessed on November 7, 2016.

Lessig, Lawrence, "CC Review: Lawrence Lessig on How It All Began", Creative Commons, https://creativecommons.org/2005/10/12/ccinreviewlawrencelessigonhowitallb egan/, accessed on October 1, 2017. 